\title{
Possibilities of Retrospective Monitoring and Value Loss Assessment of the Site Damaged by Continuous Stone Exploitation: Sutilija hill above Trogir, Croatia
}

\author{
Filomena Sirovica \\ Lujana Paraman \\ Dinko Tresić Pavičić
}

https://doi.org/10.17234/METARH.2019.3

Filomena Sirovica Archaeological Museum in Zagreb

Trg Nikole Šubića Zrinskog 19

HR - 10000 Zagreb

fsirovica@amz.hr

Lujana Paraman

Trogir Town Museum

Gradska vrata 4

HR -21220 Trogir

lujaparaman@gmail.com

Dinko Tresić Pavičić Kaducej Ltd.

Papandopulova 27

HR -21000 Split

dtresic@gmail.com

The paper analyses methodological possibilities of retrospective monitoring and value loss assessment on the archaeological records continuously subjected to harmful impacts using an example of prehistoric archaeological record preserved on Sutilija (St. Elijah's) hill in Seget Gornji above Trogir, Croatia, which is continuously subjected to stone mining that resulted in the vast devastation of the landscape, as well as the destruction of the archaeological features. This was the stimulus for the project focused on monitoring of the site with the objective to document its present state and to collect the data about changes in the landscape. Through comparison of the data collected by topographic survey and high-resolution 3D photogrammetry of the entire hill with the available archival spatial data (aerial photographs, cadastral maps etc.) a set of information was obtained that enables analysis of the changes caused by anthropogenic activities in different periods. Results of this type of analysis are suitable for the valorisation of the site, as well as a value loss assessment through different periods of contemporary stone exploitation. As the collected data enables chronological separation of the harmful impacts, the authors will present a methodological approach to the reconstruction of their effects and the possibilities that this type of analysis has for the assessment of value loss on continuously endangered archaeological sites.

Keywords: Sutilija hill, hillfort, quarries, damaged archaeological record, retrospective monitoring, value loss assessment (VLA) 


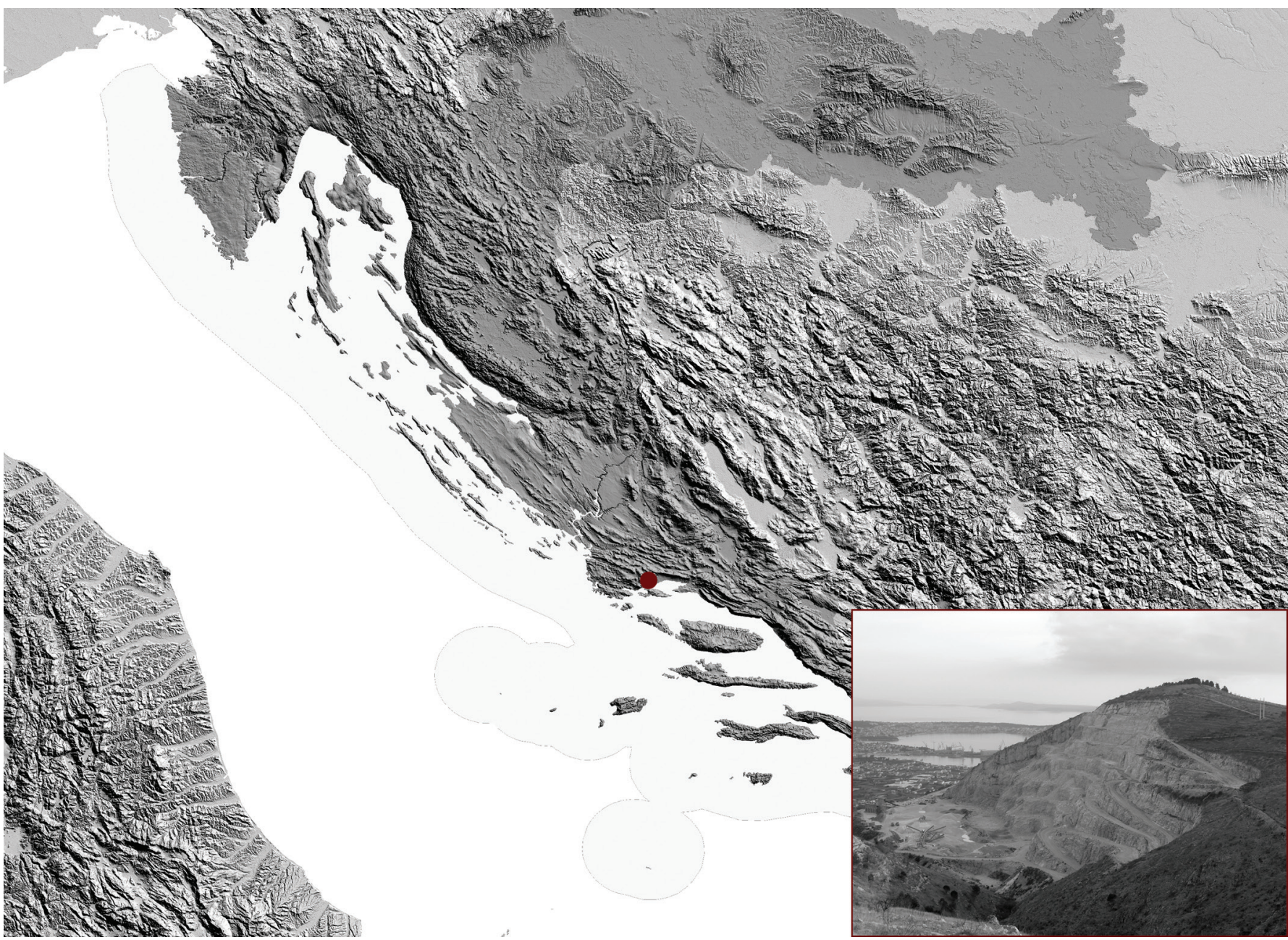

FIGURE 1. Geographical location of Sutilija hill above Trogir, Croatia (made by: D. Tresić Pavičić; photo by: L. Paraman; source: EU-DEM produced using Copernicus data and information funded by the European Union - EU-DEM layers).

\section{Introduction}

Sutilija (St. Elijah's) hill in Seget Gornji above Trogir (ancient Tragourion/Tragurium), Croatia (Fig. 1), is one of the most important sites for understanding the Late Prehistory and Protohistory of Trogir area as well as the history of quarrying in Dalmatia. This complex site with the continuity of anthropogenic activities, possibly from the Upper Paleolithic / Mesolithic to Modern Period, is characterised by two distinctive features: located on the top of the hill are the remains of the Bronze / Iron Age hillfort ${ }^{1}$ and the medieval Church of St. Elijah, while

${ }^{1}$ Sutilija was first mentioned by Cvito Fisković in 1957 (Fisković 1957: 218). The structures on the hill as well as the topography of the area were described by Ante Škobalj in 1970 (Škobalj 1970: 339, 341), while Ivo Babić interpreted the site as part of an organized network of Prehistoric hillforts in the coastal area of Trogir and Kaštela (Babić 1980: 62; Babić 1991: 32). In more recent studies, the site is understood primarily as Iron Age hillfort (Čače 1992: 36; Miletić 2008a), although archaeological remains indicate its Bronze Age origins (Kirigin 2010: the south and east slopes of the hill are occupied by the remains of quarries dated from the Roman to Modern Period. Regardless of these remains supervising institutions did not list and protect the site as cultural heritage until 2006.

As stone mining continues to this day, with three active quarries on the east and northeast slope of the hill, it is continuously subjected to harmful impacts. The shift from architectural-building to technical-building stone

31, especially n. 24. On problems of distinguishing Bronze and Iron Age remains in the Eastern Adriatic see Barbarić 2010: 311-312; Kirigin 2010: 23-24). The finds of luxury Alto-Adriatico red figure pottery collected allegedly from the destroyed grave on the north side of rampart in the 1990s (Kirigin 2010) contributed to the understanding of hillfort as an important centre of local Iron Age community possibly Hili or Bulini mentioned by the historical sources (Pseudo-Skylax 22; PseudoScymnos 403-413). 
exploitation over the last 20 years resulted in the vast devastation of the landscape, as well as the destruction of the archaeological features and only in 2011 further expansion of the quarry was prohibited.

This was the stimulus for the project focused on monitoring of the site with the objective to document its present state and to collect the data about changes in the landscape. The project started in 2013 and encompassed a desk-based assessment of archival data, field survey directed towards the recording of anthropogenic features and surface finds, and topographic survey and high-resolution 3D photogrammetry of the entire hill. The objective of the survey was to document the present state of the site and to create basic documentation for tracing and monitoring changes caused by anthropogenic activities and to form the basis for spatial and archaeological structures analysis intended for planning further research.

At the same time, through comparison of the data collected by topographic survey and high-resolution 3D photogrammetry and the available spatial data (aerial photographs, cadastral maps etc.) a set of information was obtained that enables analysis of the changes caused by anthropogenic activities in different periods. Results of this type of analysis are suitable for the valorisation of the site, as well as chronological separation of the harmful impacts. As the collected data enables retrospective assessment of loss of value in different periods of contemporary stone exploitation, the aim of this paper is to present a methodological approach to the reconstruction of their effects and the possibilities that this type of analysis has for the assessment of value loss on continuously endangered archaeological sites.

\section{Overview of conducted research}

In 2013 the Trogir Town Museum started an archaeological research project of the Sutilija hill to emphasize the archaeological potential and value of the site, through documentation of archaeological remains from all periods and an attempt of their interpretation. The objective of this research is to expand the knowledge and more precisely determine the actual significance of the site, to raise public and governmental awareness about the necessity of its extensive protection and long-term monitoring. The first phase of research included deskbased assessment of available archival data and spatial information about the site: the old photographs and postcards, aerial photographs, maps and cadastral data. It was followed by a detailed topographic survey of the site $^{2}$ which included photographic documentation and topographic measurements of approximately 70 ha. ${ }^{3}$ On collected data high-resolution 3D model was generated from which Digital Surface Model (DSM) and Digital Terrain Model (DTM) with ground sample distance of $7 \mathrm{~cm} /$ pix, and True Orthophoto with ground sample distance of $4 \mathrm{~cm} /$ pix were derived (Paraman and Tresić Pavičić 2015; Fig. 2). This high-resolution data gave a complete solution for documenting the present state of the hill while combined with other available data, such as aerial photographs and results of the field survey, serves as the basis for the development of long-term systematic monitoring of the site and surrounding landscape.

The second phase of the project included field survey of the entire hill and mapping the tool marks and rock cuts in the historic quarries. ${ }^{4}$ The objective of the field survey was to determine the area of distribution and frequency of the surface material and general chronological information about the site. Due to the vegetation covering the hill, the finds were mostly visible on or near different drywall structures. Potsherds prevail among the finds, but the fragments of stone tools (whetstone and grinding stone, lithic material), pieces of iron slag, bone and shell material were also recorded. The analysis of the pottery suggests that more pronounced usage of the area happened from the Late Bronze Age to the Hellenistic Period. Although further research is required, the scarce material evidence from $2^{\text {nd }}$ and $1^{\text {st }}$ century $B C$ suggest that human activities significantly decreased somewhere in the $3^{\text {rd }}$ century $B C$. The most intriguing finds were collected on the highest terrace of the SegetNorth quarry where the material from the damaged terrace and the destroyed speleological object, possibly a pit, is being washed down. The find of punctured sea snail Collumbela rustica along with several other lithic finds suggests possible anthropogenic activities on the hill already in the period of the Upper Paleolithic or in the Mesolithic. ${ }^{5}$

\footnotetext{
${ }^{2}$ With the financial support of the Croatian Ministry of Culture the topographic survey was carried out in 2015 in collaboration of Trogir Town Museum and archaeological company Kaducej Ltd.

3 Survey was conducted using unmanned aerial vehicle DJI Phantom and Global Navigation Satellite System Receiver Stonex S9.

${ }^{4}$ Field survey was conducted by the Trogir Town Museum and carried out in cooperation with Archaeological Museum in Zagreb. The survey of the historic quarries was carried out in cooperation with Mate Parica from University of Zadar, Department of archaeology, as part of the research for PhD thesis (Parica 2014)

${ }^{5}$ Another speleological object- a small cave, is located about $100 \mathrm{~m}$ south of the church, with recorded presence of Bronze and Iron Age as well as Hellenistic pottery.
} 


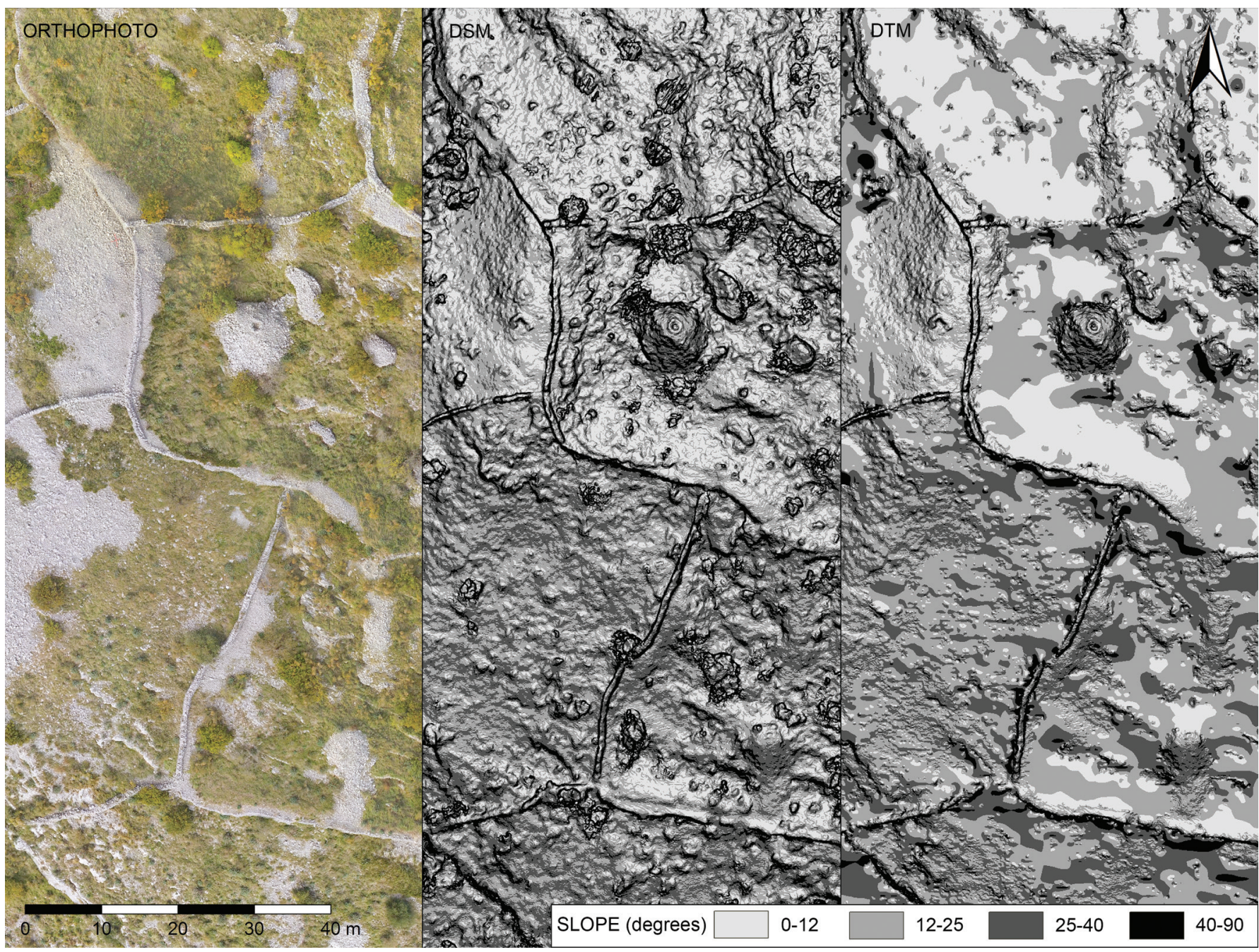

FIGURE 2. True Orthophoto, Digital Surface Model (DSM) and Digital Terrain Model (DTM) derived from high-resolution 3D model (made by: D. Tresić Pavičić).

The remains of the traditional quarrying by using socalled block method were documented and mapped. The technique of cutting a channel around the desired block in order to separate it from the parent rock, used from Roman to the Modern Period left the marks in the shape of rectangular rock cuts with the traces of hand tools (socalled strije) and cut channels (so-called pašarini) that are visible from the south to the east slopes of the hill. The difference in tool marks due to the use of heavier tools in the Roman Period and lighter tools in the later periods suggests the possibility of chronological distinction of the historic quarries, with the southern part of the slope being exploited in the Roman Period, and the western part in Medieval and Modern Period. However, most quarries were used during a longer period of time, as can be seen in Kačićeva kava, the biggest quarry on the south slope, where the remains of the exit ramp of Roman quarry were discovered in 1999 (Maršić 2007). Its interior faces are covered by tool marks from Roman to Modern Period and also by the contemporary cuts. The extensive stone exploitation over a period of 2000 years left a huge amount of waste material that covers the foot of the hill (Parica 2014: 88).

The stone mining continues to this day, with currently three active quarries located on slopes of the hill. While the traditional architectural-building stone exploitation was less destructive in its scope (but still overlaid the remains of historic quarries), the shift to technical-building stone mining after the World War II and producing of gravel on the northeast slope of the hill, which intensified during the 1970's and 1980's, resulted in greater de- 
struction of the site and surrounding landscape. As the quarrying continued, in the last 20 years Seget-North technical-building stone quarry completely wiped out the $1 / 5$ of the hill. The extent of this destruction may also be illustrated by the fact that between 2001 and 2011, when further expansion of the quarry was forbidden, the quarry increased its scope by a quarter, and 35 $\%$ of this expansion happened after 2006 when the site was for the first time listed as cultural heritage (Ministarstvo kulture Republike Hrvatske 2007a; 2007b; Narodne novine 12/2008). During that time the eastern end of the rampart was destroyed in the length of almost 60 $\mathrm{m}$, along with lover eastern terraces and the potential graves north of the rampart. According to 2008 project of quarry's south cliff remediation, new expansion, which could have resulted in the destruction of both the hillfort and the historic quarries in the area of 2.6 ha, was expected (Rudarsko-geološko-naftni fakultet 2008). Fortunately, in 2011 further expansion of the quarry was prohibited and the new propositions allow exploitation of stone only in the current extent of the quarry (Ministarstvo kulture Republike Hrvatske 2011a; 2011b; Pašalić et al. 2016).

\section{Retrospective Monitoring and Evaluation of the Site}

The documentation collected within the Sutilija project includes historical and some newer aerial photographs taken during the last 50 years in 12 unequal intervals. They are acquired from the archive of the State Geodetic Administration of the Republic of Croatia (Državna geodetska uprava Republike Hrvatske, DGU) and the topographic survey conducted in 2015. Based on the analysis of photographs, a detailed plan of the site was created by mapping all visible features with the preliminary classification of drywall structures according to their visual

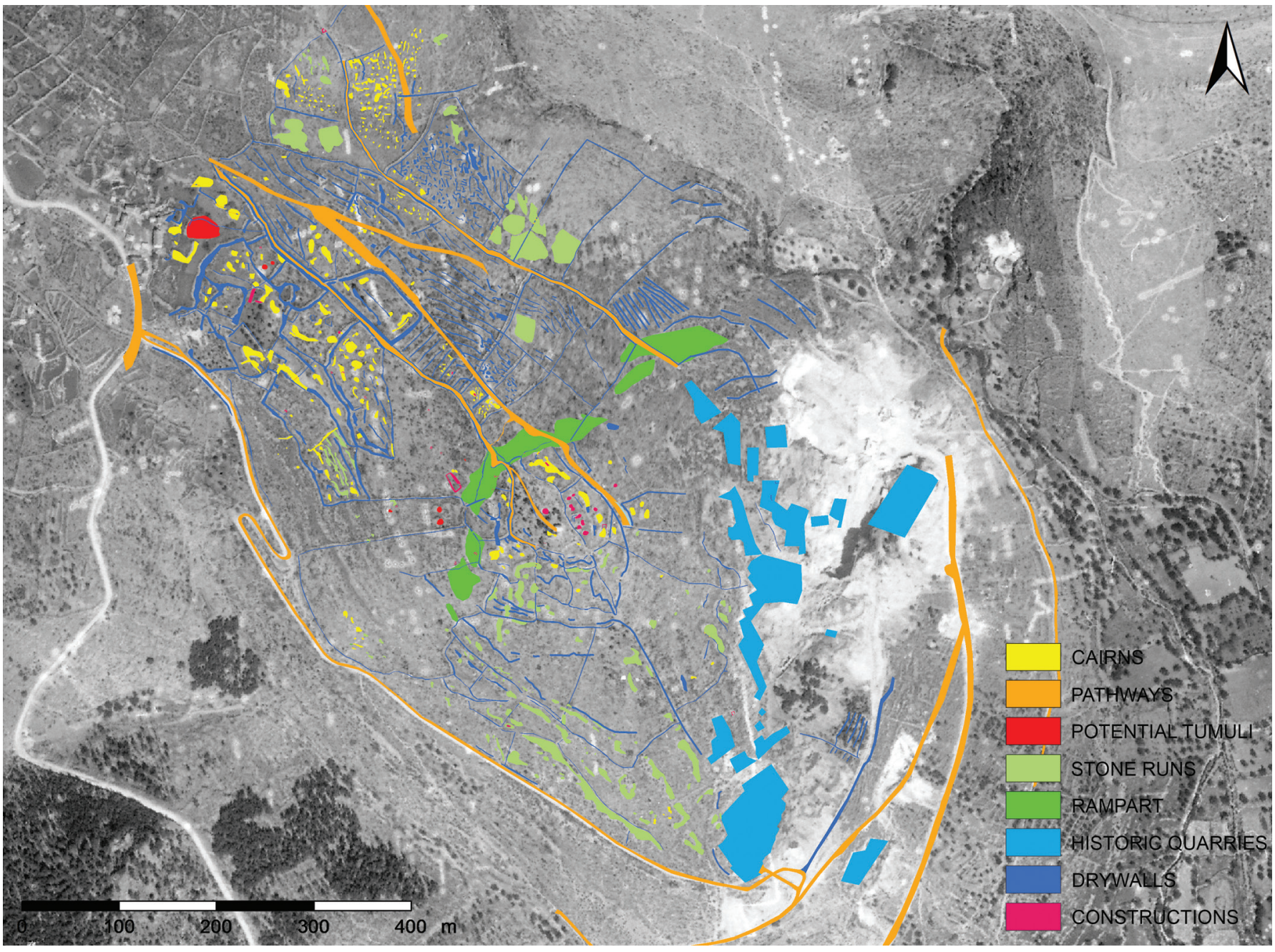

FIGURE 3. Plan of the site with classification of mapped features (made by: D. Tresić Pavičić; background: DGU, photo 1967_4465). 


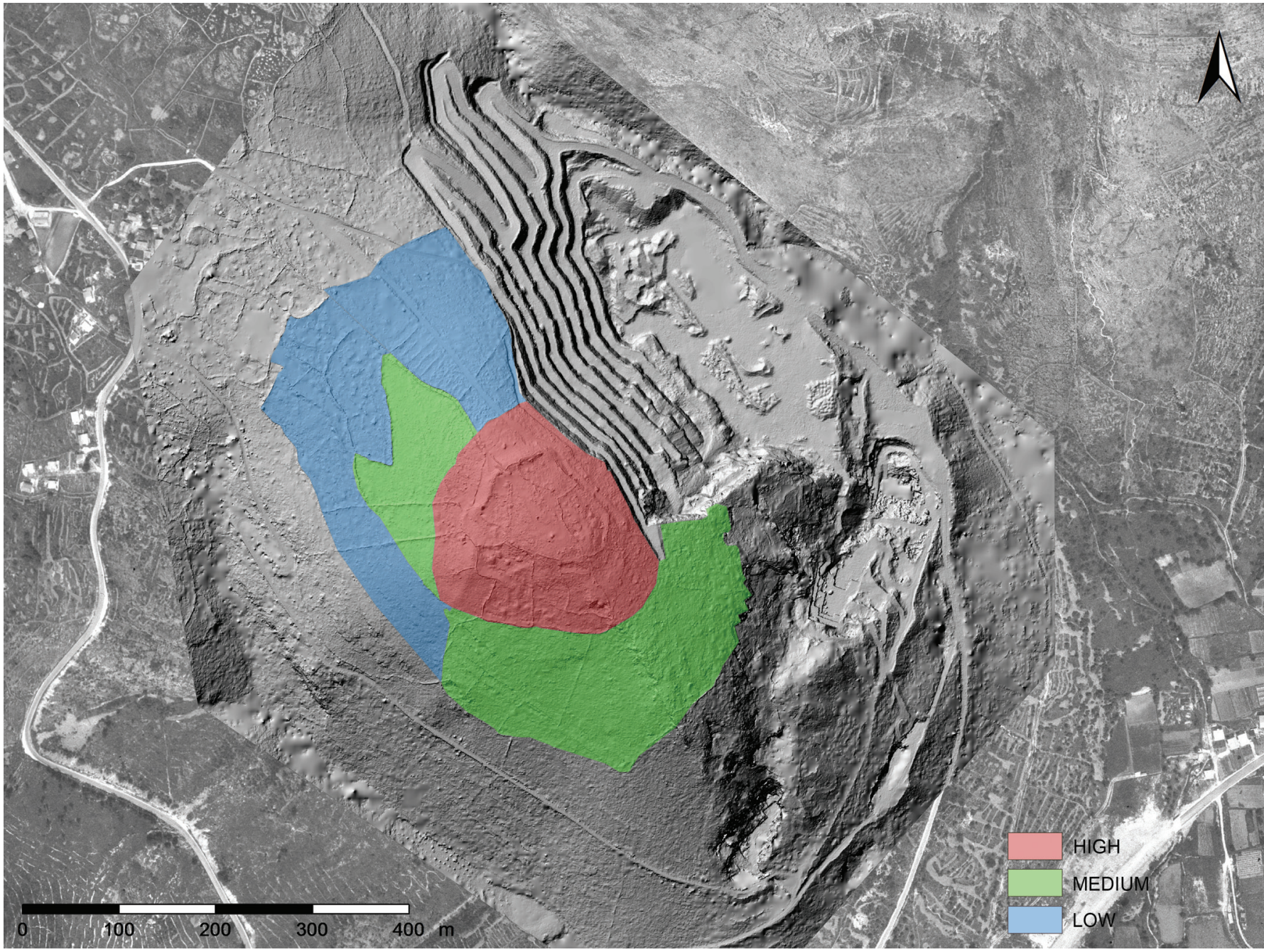

FIGURE 4. Frequency of the surface archaeological material in relation to DTM (made by: D. Tresić Pavičić; background: DGU, photo 1985_5364).

characteristic and present knowledge about their possible functions. Features were classified in 8 classes: boundary and terrace drywalls, pathways, medieval/ modern constructions, prehistoric rampart, cairns, potential tumuli, historic quarries and stone runs (Fig. 3). This data was compared with the data collected during the field survey of the hill which gave an insight into the relationship between aboveground structures and distribution and frequency of the surface finds. Results of the survey show that surface material spreads over the area of about 9 ha with higher concentrations established in the central part and on the terraces on the western slope of the hill, the area covering about 4.5 ha (Fig. 4).

The procedure also included mapping of the quarry perimeter in different periods, which enabled the separation of 8 periods of the quarry expansion that were recorded in the years 1968, 1970's, 1985, 1997, 2001,
2006, 2009 and 2011. This data provided a possibility for chronological separation of the harmful impacts which enables the establishment of the methodological approach to the reconstruction of their effects and the possibilities that this type of analysis has for the assessment of value loss on continuously endangered archaeological sites.

The procedure was carried out according to a Value Loss Assessment (VLA) Model ${ }^{6}$ which was used as a tool that can provide an insight into the possibilities of retrospective monitoring of loss of value through time but also as a method for predictive assessment of loss. The Model is based on systematic quantitative value assessments (see

\footnotetext{
${ }^{6}$ The VLA Model was developed as a part of the PhD thesis of one of the authors of this text (Sirovica 2015).
} 
for example Darvill et al. 1987; Schofield 2000; Darvill 2001; Willems and Brandt 2004) developed within the practice of preventive archaeology, a procedure for the management of endangered archaeological remains. Accordingly, applying the VLA Model to already damaged archaeological records sets clear requirements that need to be fulfilled in order for the assessment to be valid. Because of that, the method was carried out through five stages: construction of the frame of reference, assessment of value before the harmful events, assessment of the spatial extent of damage, value loss assessment, and finally categorisation of calculated loss (after Sirovica 2019: 91).

The first stage of the process is the construction of the frame of reference, a temporally and spatially defined area within which the value assessments can be carried out. According to this requirement, multi-period archae- ological records, such as the one at Sutilija, cannot be assessed on the basis of only one reference frame (Sirovica 2019: 79-81) and for trial application of the method; temporal boundaries were limited on prehistoric, i. e. Bronze to Iron Age archaeological record, for which a suitable set of data was collected. On the other hand, as such estimates basically serve to define the value of archaeological records for the purposes of national or regional archaeological heritage management; the spatial boundaries of the frame of reference were defined in accordance with the area of jurisdiction of the Ministry of Culture of Republic of Croatia Conservation Department in Trogir, which has supervision over Sutilija (Fig. 5). In this context, it can be claimed that prehistoric remains preserved at Sutilija are part of a widespread type of archaeological record that forms the basis for regional studies of the Bronze and Iron Age. It is preserved at a

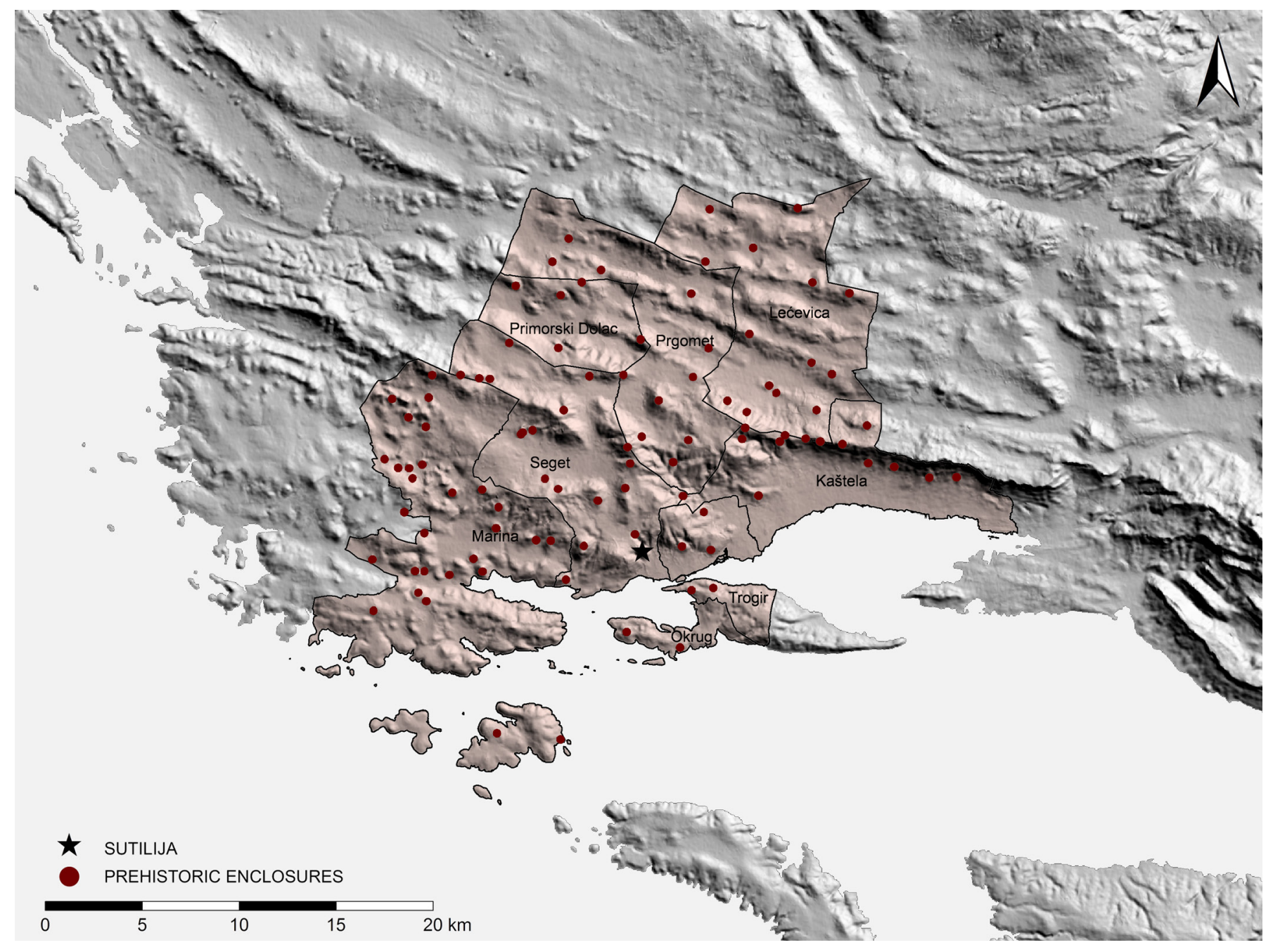

FIGURE 5. Spatial boundaries of the reference frame for value assessment of archaeological record at Sutilija (made by: D. Tresić Pavičić; background: EU-DEM produced using Copernicus data and information funded by the European Union - EU-DEM layers). 
series of positions on which contemporaneous enclosures are established. At the same time, these sites show significant variations in certain characteristics, such as accessibility and location, conducted research, preservation, dimensions, presence of above-ground structures, distribution and frequency of surface archaeological material, and the presence of synchronic and diachronic context (Babić 1980; 1991: 31-42; Čače 1992: 34-36; 2001; Katić 1994; Burić 2000; 2008; Šuta and Bartulović 2007; Madiraca 2012; Miletić 2006; 2007; 2008b; 2009; Šuta 2009; 2010; 2013a; 2013b; 2016). Analysis of these specific features significantly influence the assessment of

\begin{tabular}{|c|c|c|c|}
\hline \multirow{3}{*}{ SOCIAL VALUES } & VISUAL VALUE & $\begin{array}{l}\text { Sutilija hill, located on the western edge of Trogir field, dominates the } \\
\text { surrounding landscape and offers a great vantage point of the field and } \\
\text { coastal waters around Trogir. The prehistoric archaeological record is } \\
\text { marked by visible structures and features; in particular by the remains of } \\
\text { the rampart which are a visually impressive point in the landscape. The } \\
\text { position of the site, near main communication between Trogir and hin- } \\
\text { terland makes it a significant part of the contemporary landscape. It can, } \\
\text { therefore, be considered as a major element of the landscape identity, } \\
\text { with great influence on the experience of the place and space. }\end{array}$ & 3 \\
\hline & HISTORICAL VALUE & $\begin{array}{l}\text { Historical development of the site is directly related to historical events } \\
\text { in the wider Trogir region, especially in the late Iron Age and Hellenistic } \\
\text { period, at the same time complementing the understanding of landscape } \\
\text { usage in prehistory. The significance of the position as evocative stimuli is } \\
\text { reflected through continuity of its usage as a sacred site from the Middle } \\
\text { Ages, when the church of St. Elijah was built, and through the presence } \\
\text { of local legends related to the place that contribute to its contemporary } \\
\text { interpretation. }\end{array}$ & 3 \\
\hline & ECONOMIC VALUE & $\begin{array}{l}\text { Physical and symbolic characteristics of the site make it part of different } \\
\text { segments of contemporary social life while immediate vicinity of heritage } \\
\text { and tourist centres - Trogir and Seget enable its direct inclusion in exist- } \\
\text { ing tourist and recreational or educational and cultural offer. Although it } \\
\text { is not possible to claim that such models of site utilization would provide } \\
\text { direct economic benefits, as part of a wider tourist offer, it certainly has } \\
\text { the potential to generate noticeable indirect value. }\end{array}$ & 2 \\
\hline \multirow{3}{*}{ GENERAL VALUES } & RARITY & $\begin{array}{l}\text { Archaeological record at Sutilija hill can be compared to a large number } \\
\text { of concurrent archaeological remains in the region. However, its scope, } \\
\text { preservation and characteristics of visible structures and features, the } \\
\text { quantity and variety of surface and subsurface archaeological remains, } \\
\text { as well as the presence of imported Hellenistic finds indicate that the ar- } \\
\text { chaeological record is directly comparable with only one known archaeo- } \\
\text { logical site within the predefined frame of reference. }\end{array}$ & 2 \\
\hline & GROUP VALUE & $\begin{array}{l}\text { Within the predefined frame of reference, Sutilija is the only known Iron } \\
\text { Age site with necropolis in the immediate vicinity of settlement remains. } \\
\text { At the same time, the presence of stone mounds, as well as different } \\
\text { prehistoric remains in the immediate vicinity indicates the pronounced } \\
\text { synchronic context and the exceptional preservation of the prehistoric } \\
\text { landscape. On the other hand, archaeological finds from earlier pre- } \\
\text { historic periods, traces of stone exploitation from the Roman Period to } \\
\text { modern times, elements of medieval sacral architecture and cemetery as } \\
\text { well as other remains attest the continuous significance of the position } \\
\text { and affirm the presence of exceptional diachronic context. }\end{array}$ & 3 \\
\hline & REPRESENTATIVENESS & $\begin{array}{l}\text { The prehistoric archaeological record at Sutilija site, despite many specif- } \\
\text { ic elements, can be considered as a representative archaeological record } \\
\text { that contains characteristic features for both the period and the region. } \\
\text { The record emerged in specific historical conditions and it is directly com- } \\
\text { parable to some of the known and preserved archaeological sites. }\end{array}$ & 2 \\
\hline
\end{tabular}




\begin{tabular}{|c|c|c|c|}
\hline VALUES & CRITERIA & QUALITATIVE VALUE ANALYSIS & $\begin{array}{l}\text { QUANTITA- } \\
\text { TIVE VALUE }\end{array}$ \\
\hline \multirow{4}{*}{ SCIENTIFIC VALUES } & INTEGRITY & $\begin{array}{l}\text { The position had indisputable spatial integrity accompanied by archaeo- } \\
\text { logical remains at the place of primary deposition, but the level of direct } \\
\text { threat has not diminished since the middle of last century. The current } \\
\text { state of the site demonstrates subjection to the long-term harmful im- } \\
\text { pacts caused by human activities that have seriously undermined the } \\
\text { integrity of the site and the wider landscape. Currently, the environment } \\
\text { is relatively stable, without the possibilities for the occurrence of rapid } \\
\text { changes, but the level of integrity value will depend on future manage- } \\
\text { ment plans for the area. }\end{array}$ & 2 \\
\hline & QUALITY & $\begin{array}{l}\text { Despite the devastation, there is still a significant level of preserved ar- } \\
\text { chaeological remains: standing structures, features, deposits; which form } \\
\text { readable stratigraphic sequence marked by the diverse archaeological } \\
\text { finds. Presence of the well-preserved diagnostically relevant material in- } \\
\text { dicates that in comparison to records of the same period in the region, it } \\
\text { is a high-quality archaeological record. }\end{array}$ & 3 \\
\hline & $\begin{array}{l}\text { INFORMATIONAL } \\
\text { POTENTIAL }\end{array}$ & $\begin{array}{l}\text { Although it is an archaeological record of lower complexity, in compari- } \\
\text { son with other concurrent records in the region, it shows exceptional po- } \\
\text { tential for obtaining data on formal features of archaeological remains } \\
\text { and their contextual interrelations. It can enable considerations on the } \\
\text { activities that caused its emergence and meaningful interpretations of } \\
\text { the spatial and temporal dimension of human activities. At the same } \\
\text { time, the information potential of the record is directly dependent on } \\
\text { the integrity of the site- and varies depending on future interventions in } \\
\text { the area and potential new devastations. }\end{array}$ & 3 \\
\hline & $\begin{array}{l}\text { INTERPRETATIVE } \\
\text { POTENTIAL }\end{array}$ & $\begin{array}{l}\text { It can be argued that the archaeological record contains clear interpreta- } \\
\text { tive potential, with the ability to fill the gaps in current knowledge. This } \\
\text { is particularly pronounced considering the specific connection between } \\
\text { Iron Age settlement and cemetery, as well as the relations with concur- } \\
\text { rent settlement remains in the area of Trogir. It has the ability to generate } \\
\text { new knowledge through comparison with results of recent research of } \\
\text { the period in which it has significance above the regional level. }\end{array}$ & 3 \\
\hline \multicolumn{2}{|l|}{ TOTAL VALUE } & HIGH QUALITY RECORD & 26 \\
\hline \multicolumn{3}{|c|}{ VALUE INDEX (Vi = TV / 10) } & 2,6 \\
\hline
\end{tabular}

TABLE 1. Value assessment of prehistoric archaeological record at Sutilija.

value understood as the relevance of individual archaeological record for contemporary society as well as the analysis of its general attributes and their informational potential. Therefore, it is possible to distinguish only one somewhat comparable site in the defined region: Sv. Nofar in Bijaći (Čače 1992: 35, 39; Čače and Milivojević 2017: 437, Map 1; Šuta 2011: 26; Šuta and Bartulović 2007: 14, 19); although several locations, where wellpreserved structures and the presence of large quantities of prehistoric material were recorded, are likely to represent the remains of larger concurrent settlements: Oriješćak above Vinišće, Drid above Marina, Čurkovac above Bristivica, Grad above Blizna Gornja, Gradina near Mateljani in Bogdanović, Luko in Kaštel Sućurac (Čače
1992: 35-36; Katić 1994; Miletić 2006; 2007; 2009: 10; Šuta and Bartulović 2007: 19; Burić 2008; Šuta 2009: 153; 2016: 26-29); for which it can be presumed to have considerable potential for filling the large gaps in current knowledge about the time period in question.

The second stage consists of value assessment which was carried out according to a set of 10 predefined criteria separated in three categories: social, general and scientific value; complemented by numerical values for every parameter (Sirovica 2019: 77-84). By assigning points from 1 to 3 to each criterion, corresponding to the assessment of low, medium and high value; expression of value in the form of a number was enabled. From 
possible 30 points, Sutilija's prehistoric archaeological record gained 26, and it is rated as a high-value archaeological record with a value index, calculated as a ratio between the total score and a number of used criteria, of 2.6 (Table 1$).^{7}$

\section{Value Loss Assessment}

For the successful application of the VLA Model to prehistoric archaeological record at Sutilija, it was necessary to estimate the percentage of damage (EPd) expressed as the ratio between the spatial scope of the destruction or damaged area (Da) and the total area of the comparable archaeological record (CAR; Sirovica 2019: 84). ${ }^{8}$

$\operatorname{EPd}[\%]=100 \times \frac{\mathrm{Da}}{\mathrm{CAR}}$
Defining the spatial extent of damage caused by the quarry required the analysis based on topographic features of the area, aerial photographs, historical and contemporary cadastral data, as well as archaeological analysis of aboveground structures and the results of the field survey. Combined, these newly acquired and historical data enabled the reconstruction of certain features of the hill in different periods and indicated clear differences between areas with different topographic characteristics. Accordingly, the prehistoric archaeological record was divided into 5 separate zones (Table 2) which differ in the configuration of the terrain, usage of space in recent periods, the types of above-ground remains of anthropogenic origin, the frequency of surface archaeological material, etc. Zones were labelled with numbers from 1 to 5 and descriptively defined as the central zone, the zone of pronounced activity, the zone of approach

\begin{tabular}{|c|c|c|c|c|c|c|}
\hline ZONE & DESCRIPTION & TERRAIN & $\begin{array}{l}\text { SURFACE } \\
\text { MATERIAL } \\
\text { FREQUENCY }\end{array}$ & $\begin{array}{l}\text { STRUCTURES } \\
\text { FREQUENCY }\end{array}$ & $\begin{array}{l}\text { COMMON TYPE OF } \\
\text { STRUCTURES }\end{array}$ & USAGE \\
\hline 1 & CENTRAL ZONE & Plateau & High & Medium & $\begin{array}{c}\text { Prehistoric rampart } \\
\text { and boundary } \\
\text { drywalls }\end{array}$ & $\begin{array}{l}\text { Larger flat grassy terraces } \\
\text { with church and graveyard, } \\
\text { surrounded by large drywalls }\end{array}$ \\
\hline 2 & $\begin{array}{l}\text { ZONE OF } \\
\text { PRONOUNCED } \\
\text { ACTIVITY }\end{array}$ & Mild slope & Medium & Low & $\begin{array}{c}\text { Boundary and terrace } \\
\text { drywalls }\end{array}$ & $\begin{array}{l}\text { Mild grassy slopes with } \\
\text { vineyards at borderlines }\end{array}$ \\
\hline 3 & $\begin{array}{l}\text { PERIPHERAL } \\
\text { ZONE }\end{array}$ & Steep slope & Low & High & Terrace drywalls & $\begin{array}{l}\text { Narrow cascaded } \\
\text { agricultural terraces } \\
\text { (vineyards) }\end{array}$ \\
\hline 4 & $\begin{array}{l}\text { ZONE OF } \\
\text { APPROACH }\end{array}$ & Mild slope & Medium & High & $\begin{array}{l}\text { Pathways and drywall } \\
\text { structures }\end{array}$ & $\begin{array}{l}\text { Pathways surrounded with } \\
\text { agricultural areas }\end{array}$ \\
\hline 5 & $\begin{array}{l}\text { PERIPHERAL } \\
\text { ZONE }\end{array}$ & Steep slope & Low & Low & Stone runs & $\begin{array}{c}\text { Infertile area of broad karstic } \\
\text { slopes }\end{array}$ \\
\hline
\end{tabular}

TABLE 2. Classification of archaeological record at Sutilija by zones.

\footnotetext{
${ }^{7}$ Value assessment conducted within the VLA Model should be focused on the value that the archaeological record had before the damage oc curred (Sirovica 2019: 81). As it was possible to determine 8 separate harmful events, essentially separate assessment of value for every one of them would be needed. However, as value is a changeable social construct and neither an objective category nor inherent property of things it should be emphasized that physical damage can have very different effects on different categories of value. By analysing the value of the archaeological record at Sutilija in three categories, it can be argued that stone exploitation did not significantly change the value in first two categories, although it should be pointed out that this claim is possible only from the present perspective and potential past values according to the same or different criteria or parameters are not ascertainable. On the other hand, the value necessarily decreases in the third category, especially in the terms of integrity that is continuously
}

harmed throughout all assessment periods, but also directly threatened before the first quarry activities. As the value according to the integrity criterion should be considered decreased already with the appearance of the direct threat, the value of the archaeological record can be considered decreased by that criterion and with that somewhat uniform for all time periods.

${ }^{8}$ According to the VLA model, calculations are performed based on the two-dimensional spatial data so the damaged part can only be analysed in relation with those parts of the record for which it can be presumed to possess similar characteristics in three-dimensional space. As the definition of a CAR represents the most important part of the process that depends on the professional assessment of the depositional processes, the procedure requires the definition of the area for which it can be claimed to contain archaeological remains of comparable quality and informational potential (Sirovica 2019: 83). 


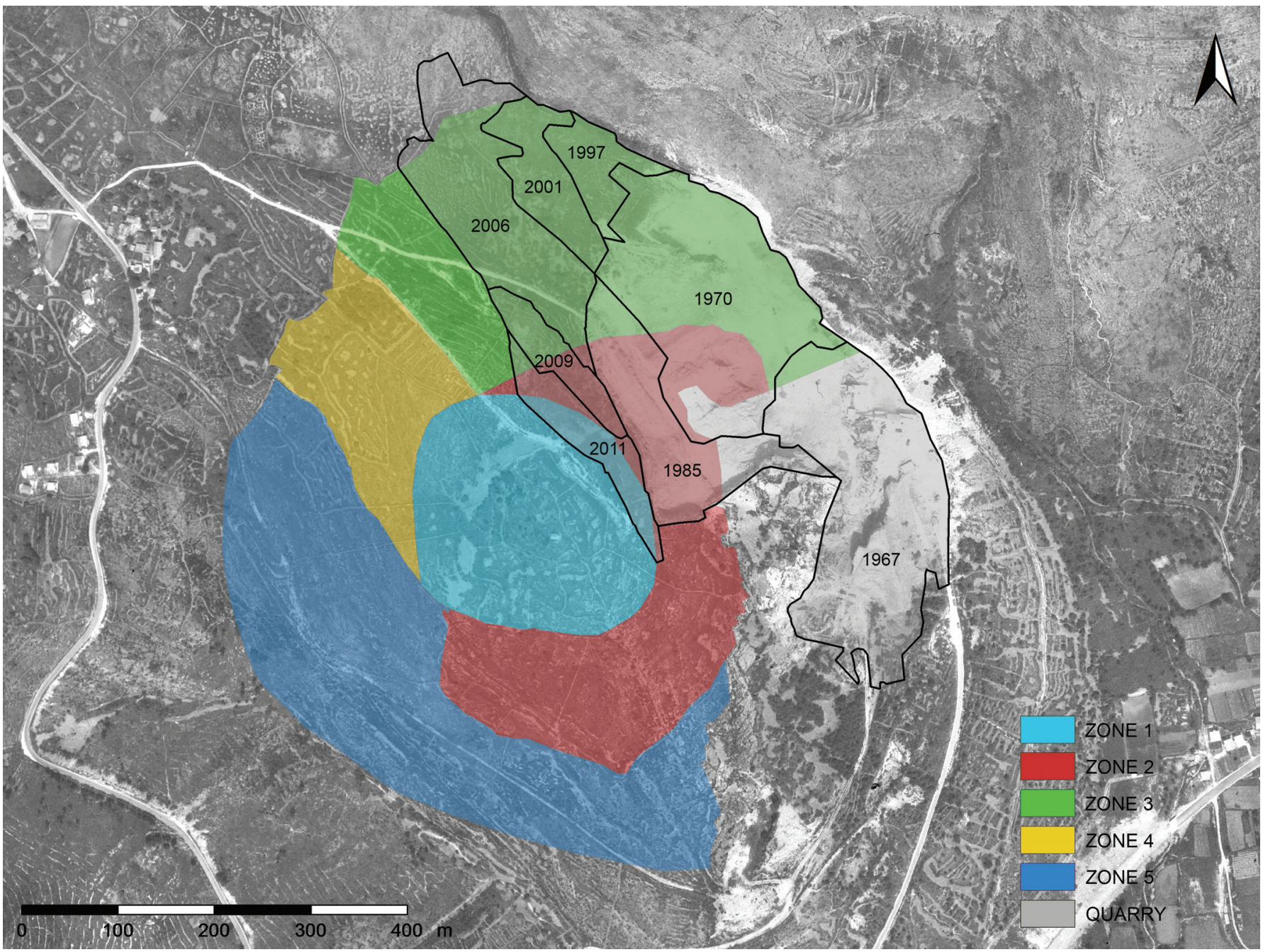

FIGURE 6. Zones of comparable archaeological record (CAR; made by: D. Tresić Pavičić; background: DGU, photo 1985_5364).

and two peripheral zones. ${ }^{9}$ This procedure enabled the determination of spatial units that can be defined as areas of CAR (Fig. 6).

In accordance with this, harmful impacts per Zone in a specific period were calculated (Table 3; Fig. 7, 8). The data derived shows that Zone 3 suffered the most extensive damage and to this day $79 \%$ of its surface disappeared. This process started more than 50 years ago and lasted until 2011. Zone 2 was first affected in the 1970s,

\footnotetext{
${ }^{9}$ The area of historic quarry was not included in the analysis as it today also represents an element of heritage and can be considered a specific type of archaeological record with different temporal and spatial characteristics. As it was also subjected to extensive damage, it needs a separate evaluation.
}

and it will be subjected to extensive destruction for the next decade. After a prolonged stagnation, minor damage was again visible in 2006, and by $201139 \%$ of this area was destroyed. On the other hand, interventions in Zone 1 started only in 2009, but until 2011, as much as $10 \%$ of the area was destroyed. If the collected data is considered in total, it can be emphasized that from the total area of all three zones, almost half of it was destroyed in the last 50 years while in relation to the complete prehistoric archaeological record on Sutilija, in this time period almost third of it disappeared (Fig. 9).

As an attempt to get a meaningful and well-founded assessment of damage, the relationship between the value of the archaeological record and the extent of the damage was examined. In the VLA model, loss of value represents the relationship between the attributed value and 


\begin{tabular}{|c|c|c|c|c|c|c|c|c|}
\hline & \multicolumn{4}{|c|}{$\mathrm{Da} \mathrm{m}^{2}$} & \multicolumn{4}{|c|}{$\mathrm{DaG} \mathrm{m}^{2}$} \\
\hline & $\mathbf{Z 1}$ & $\mathbf{Z 2}$ & $\mathbf{Z 3}$ & CAR & $\mathbf{Z 1}$ & $\mathbf{Z 2}$ & $\mathrm{Z3}$ & CAR \\
\hline 1968 & $\mathrm{~N}$ & $\mathrm{~N}$ & 1775 & 1775 & $\mathrm{~N}$ & $\mathrm{~N}$ & 1775 & 1775 \\
\hline $1970 \mathrm{~s}$ & $\mathrm{~N}$ & 8062 & 29194 & 37256 & $\mathrm{~N}$ & 8062 & 30969 & 39031 \\
\hline 1985 & $\mathrm{~N}$ & 13280 & 2350 & 15630 & $N$ & 21342 & 33319 & 54661 \\
\hline 1997 & $\mathrm{~N}$ & $\mathrm{~N}$ & 6448 & 6448 & $\mathrm{~N}$ & 21342 & 39767 & 61109 \\
\hline 2001 & $\mathrm{~N}$ & $\mathrm{~N}$ & 9628 & 9628 & $\mathrm{~N}$ & 21342 & 49395 & 70737 \\
\hline 2006 & $\mathrm{~N}$ & 348 & 20840 & 21188 & $\mathrm{~N}$ & 21690 & 70235 & 91925 \\
\hline 2009 & $\mathrm{~N}$ & 2822 & 3071 & 5893 & $\mathrm{~N}$ & 24512 & 73306 & 97818 \\
\hline \multirow[t]{3}{*}{2011} & 5150 & 2755 & 552 & 8457 & 5150 & 27267 & 73858 & 106275 \\
\hline & \multicolumn{4}{|c|}{ EPd \% } & \multicolumn{4}{|c|}{ EPdG \% } \\
\hline & $\mathbf{Z 1}$ & $\mathbf{Z 2}$ & $\mathbf{Z 3}$ & CAR & $\mathbf{Z 1}$ & $\mathbf{Z 2}$ & $\mathbf{Z 3}$ & CAR \\
\hline 1968 & $\mathrm{~N}$ & $\mathrm{~N}$ & 2 & 1 & $\mathrm{~N}$ & N & 2 & 1 \\
\hline 1970 s & $\mathrm{N}$ & 11 & 31 & 17 & $\mathrm{~N}$ & 11 & 33 & 18 \\
\hline 1985 & $\mathrm{~N}$ & 19 & 3 & 7 & $N$ & 30 & 36 & 25 \\
\hline 1997 & $\mathrm{~N}$ & $\mathrm{~N}$ & 7 & 3 & $\mathrm{~N}$ & 30 & 43 & 28 \\
\hline 2001 & $\mathrm{~N}$ & $\mathrm{~N}$ & 10 & 4 & $\mathrm{~N}$ & 30 & 53 & 32 \\
\hline 2006 & $\mathrm{~N}$ & 1 & 22 & 10 & $\mathrm{~N}$ & 31 & 75 & 42 \\
\hline 2009 & $\mathrm{~N}$ & 4 & 3 & 3 & $\mathrm{~N}$ & 35 & 78 & 45 \\
\hline 2011 & 10 & 4 & 1 & 4 & 10 & 39 & 79 & 49 \\
\hline
\end{tabular}

Table 3. Calculation of EPd and its growth per Zone through time.

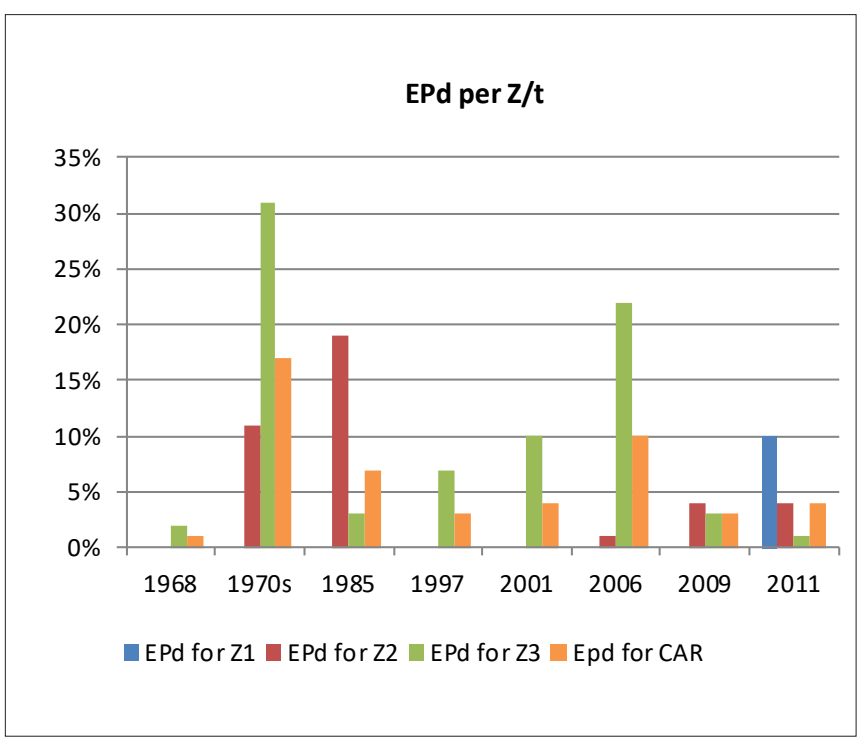

FIGURE 7. EPd per Zone through time.

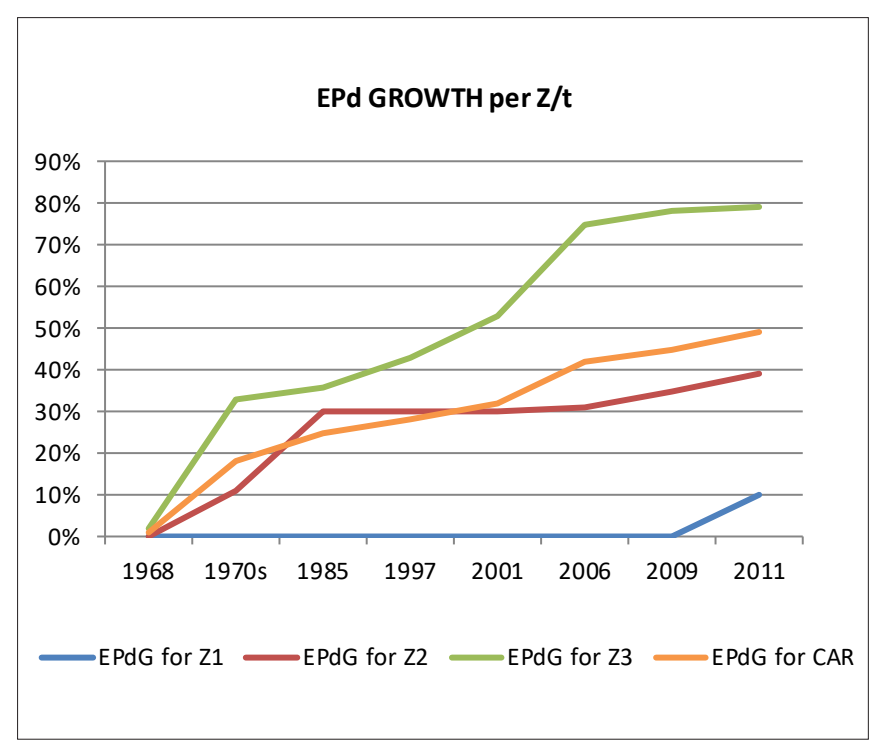

FIGURE 8. Growth of EPd per Zone through time. 
the harmful impact. In accordance with the Model, the estimation of loss (L) on highly valued archaeological records, like the one at Sutilija, requires the use of logarithmic equation which can treat any damage as significant (Sirovica 2019: 142-143).

$L=V i \times\left(\operatorname{ceil}\left(5 \times \ln \left(\frac{E P d}{20}+1\right)\right)+1\right)$

Regardless of the equation used, in VLA Model the loss will always result in values ranging from 2 to 30 . This wide interval of values requires categorization that can enable meaningful expression of loss of value. In the recommended procedure categorization of loss (LC) is carried out by a linear distribution of the obtained values using the equation which can express the loss in 5 classes corresponding to the estimates from minimal to the total loss of value (Sirovica 2019: 91, 142-143).

$L c=\operatorname{ceil}\left(\frac{L}{6}\right)$

According to logarithmic equation loss of value was calculated for each of the defined zones and comparable archaeological record in total (Table 5). The calculations, therefore, include the data on loss of value for each of the considered periods of quarry expansion (Fig. 10) and then the growth of loss with the expansion of quarry through time (Fig. 11). The substantial loss occurred in the second period and then, after a prolonged period of moderate expansion of the quarry, the loss has again drastically increased at the beginning of this century.

But the loss calculated in this way has a wide range of values (the lowest is 2.6, and the highest is 23.4 ) which is why it is necessary to express it in a way that will allow ranking the severity of damage. The equation for the linear distribution of obtained results enables the grada-

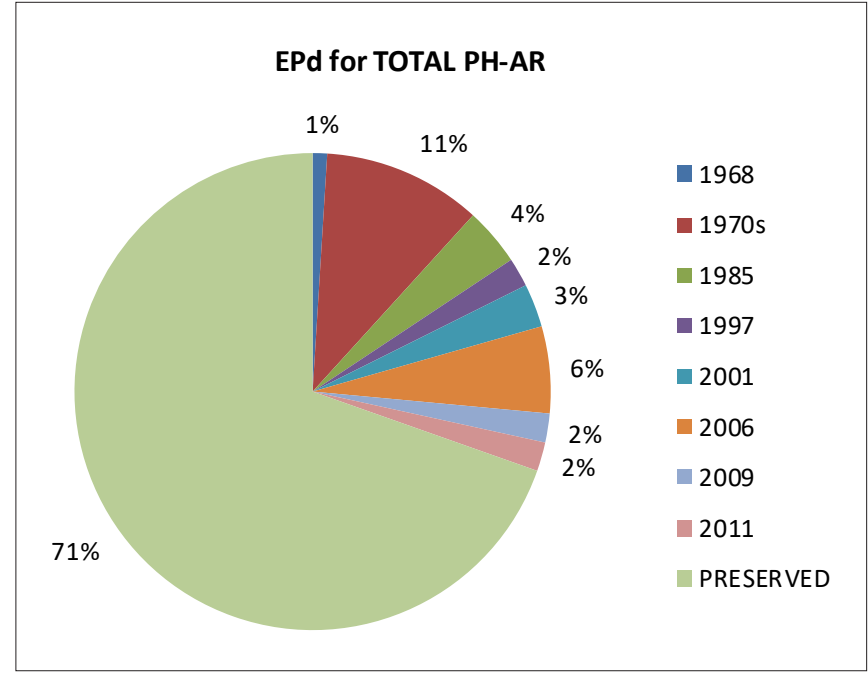

FIGURE 9. Epd for complete prehistoric archaeological record (PH-AR) on Sutilija per time period.

tion of loss (Table 6). By this procedure loss on Sutilija for each of the Zones in periods of quarry expansion is mostly expressed as minimal or moderate, i. e. with grades 1 and 2, but three times in a single period loss reached category 3 which is expressed as significant (Fig. 12). By observing the increase in damage over the years (Fig. 13), it can be noticed that in Zone 3 the loss grows from minimal (1) to significant (3) already in the second period. About a decade later it will become severe and expressed with grade 4 . In the same period loss in Zone 2 becomes significant (3) and, after a prolonged period of stagnation, in 2006 severe loss (4) is documented. The expansion of quarry between 2009 and 2011 will cause moderate damage in Zone 1 expressed with grade 2 . If we consider the affected area in total for all three zones,

\begin{tabular}{|c|c|c|}
\hline \multirow{2}{*}{ LOSS OF VALUE } & LANEAR CATEGORISATION OF VALUE LOSS \\
\hline $2-6$ & 1 & STATEMENT \\
\hline $6,1-12$ & 2 & MINIMAL LOSS \\
\hline $12,1-18$ & 3 & MODERATE LOSS \\
\hline $18,1-24$ & 4 & SIGNIFICANT LOSS \\
\hline $24,1-30$ & 5 & SEVERE LOSS \\
\hline
\end{tabular}

TABLE 4. Outcome of linear categorisation of value loss with graded statements for obtained results (Sirovica 2019: 91, Fig. 42). 


\begin{tabular}{|c|c|c|c|c|c|c|c|c|}
\hline & \multicolumn{4}{|c|}{$L$} & \multicolumn{4}{|c|}{ LG } \\
\hline & $\mathrm{Z1}$ & $\mathrm{Z2}$ & $\mathrm{Z3}$ & CAR & $\mathrm{Z1}$ & $\mathrm{Z} 2$ & Z3 & CAR \\
\hline 1968 & $N$ & $\mathrm{~N}$ & 5.2 & 5.2 & $\mathrm{~N}$ & $N$ & 5.2 & 5.2 \\
\hline $1970 \mathrm{~s}$ & $N$ & 10.4 & 15.6 & 13.0 & $\mathrm{~N}$ & 10.4 & 15.6 & 13.0 \\
\hline 1985 & $N$ & 13.0 & 5.2 & 7.8 & $\mathrm{~N}$ & 15.6 & 18.2 & 15.6 \\
\hline 1997 & $N$ & $\mathrm{~N}$ & 7.8 & 5.2 & $\mathrm{~N}$ & 15.6 & 18.2 & 15.6 \\
\hline 2001 & $N$ & $\mathrm{~N}$ & 10.4 & 5.2 & $N$ & 15.6 & 20.8 & 15.6 \\
\hline 2006 & $\mathrm{~N}$ & 5.2 & 13.0 & 10.4 & $\mathrm{~N}$ & 15.6 & 23.4 & 18.2 \\
\hline 2009 & $N$ & 5.2 & 5.2 & 5.2 & $\mathrm{~N}$ & 18.2 & 23.4 & 18.2 \\
\hline 2011 & 10.4 & 5.2 & 5.2 & 5.2 & 10.4 & 18.2 & 23.4 & 20.8 \\
\hline
\end{tabular}

TABLE 5. Calculation of loss and its growth per Zone through time.

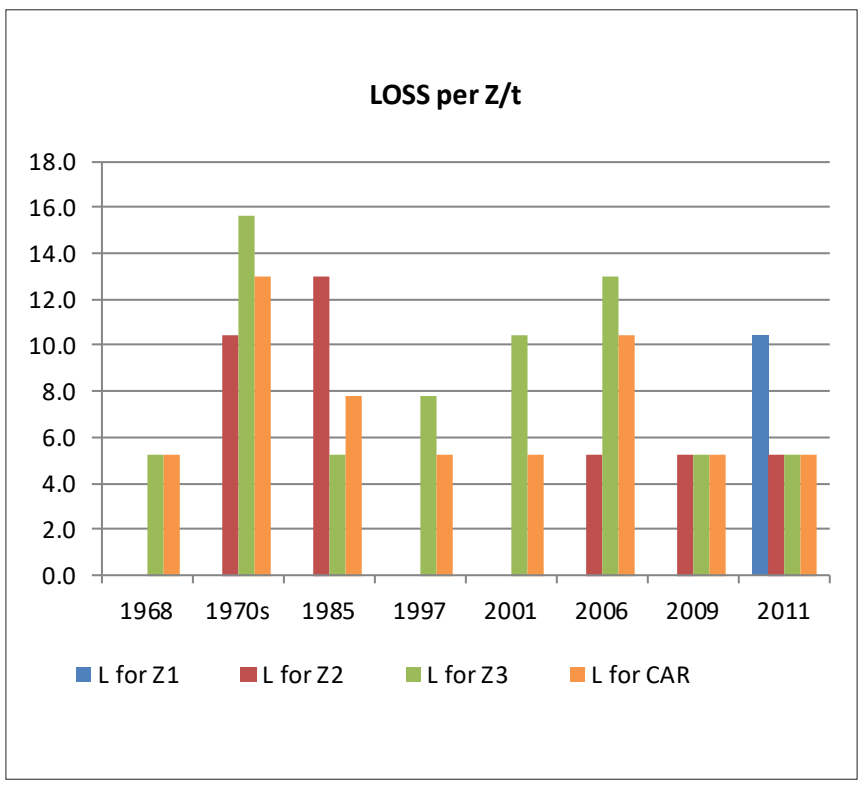

FIGURE 10. Loss per Zone through time.

already in the 1970s the loss becomes significant and expressed with grade 3 . After this period, the expansion of quarry is moderate, and the loss of value does not show visible growth. However, at the beginning of this century, with re-intensification of the quarrying activities, the loss is again rapidly increasing, and until 2006 it becomes severe and expressed with grade 4 .

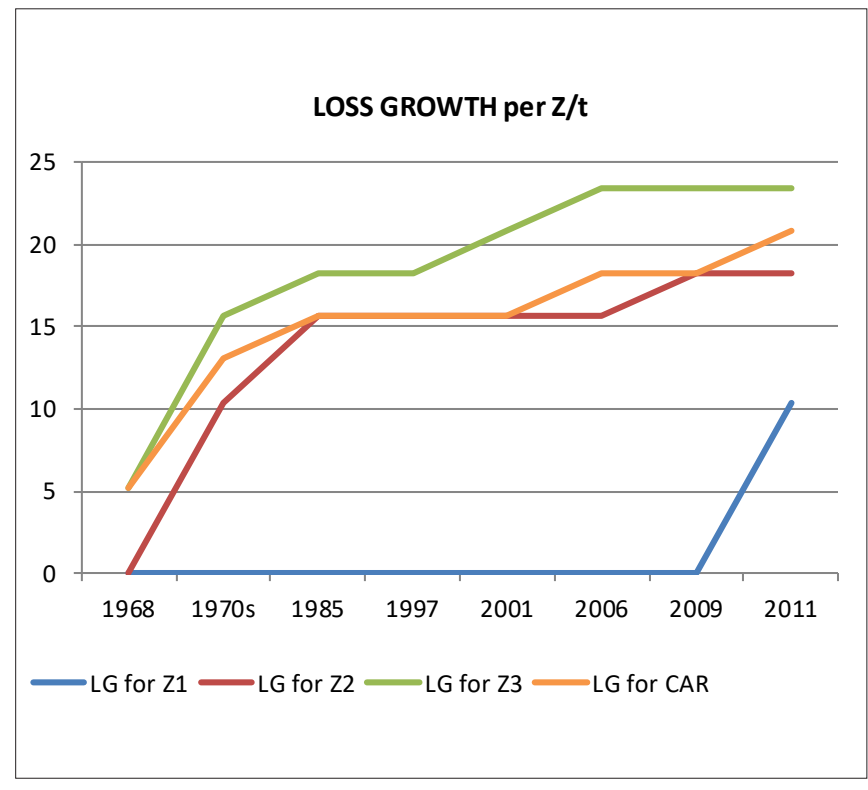

FIGURE 11.Growth of loss per Zone through time.

Visible damages to the archaeological record can be monitored until 2011 when further expansion of quarry was prohibited. However, according to the plans for quarry expansion from 2008 (Rudarsko-geološko-naftni fakultet 2008; Fig. 14) it is possible to make some anticipative assumptions on possible effects of planned activities on prehistoric archaeological record at Sutilija 


\begin{tabular}{|c|c|c|c|c|c|c|c|c|}
\hline & \multicolumn{4}{|c|}{ Lc } & \multicolumn{4}{|c|}{ LcG } \\
\hline & $\mathrm{Z1}$ & $\mathrm{Z2}$ & Z3 & CAR & $\mathrm{Z1}$ & $\mathrm{Z2}$ & Z3 & CAR \\
\hline 1968 & $N$ & $\mathrm{~N}$ & 1 & 1 & $\mathrm{~N}$ & $N$ & 1 & 1 \\
\hline $1970 \mathrm{~s}$ & $N$ & 2 & 3 & 3 & $\mathrm{~N}$ & 2 & 3 & 3 \\
\hline 1985 & $\mathrm{~N}$ & 3 & 1 & 2 & $\mathrm{~N}$ & 3 & 4 & 3 \\
\hline 1997 & $N$ & $\mathrm{~N}$ & 2 & 1 & $\mathrm{~N}$ & 3 & 4 & 3 \\
\hline 2001 & $N$ & $\mathrm{~N}$ & 2 & 1 & $\mathrm{~N}$ & 3 & 4 & 3 \\
\hline 2006 & $N$ & 1 & 3 & 2 & $\mathrm{~N}$ & 3 & 4 & 4 \\
\hline 2009 & $N$ & 1 & 1 & 1 & $\mathrm{~N}$ & 4 & 4 & 4 \\
\hline 2011 & 2 & 1 & 1 & 1 & 2 & 4 & 4 & 4 \\
\hline
\end{tabular}

TABLE 6. Categorisation of loss and growth of categorised per Zone through time.

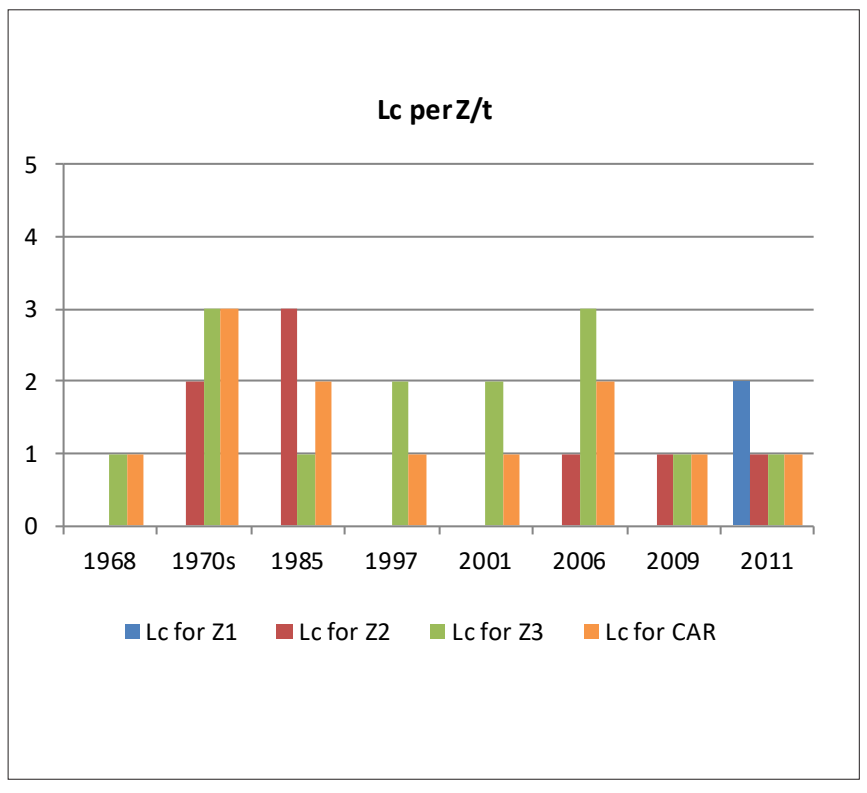

FIGURE 12. Categorisation of loss per Zone through time.

(Table 7, Fig. 13). The new expansion would again seize all three zones in a total area of 0.7 ha or the new $3 \%$. This would result in damage estimated to $12 \%$ in Zone 1 , $46 \%$ in Zone 2 , and $80 \%$ in Zone 3 , while the damage in all three zones would for the first time increase over 50 $\%$. Nevertheless, the calculations and categorisations of loss would mostly remain the same, but it is important

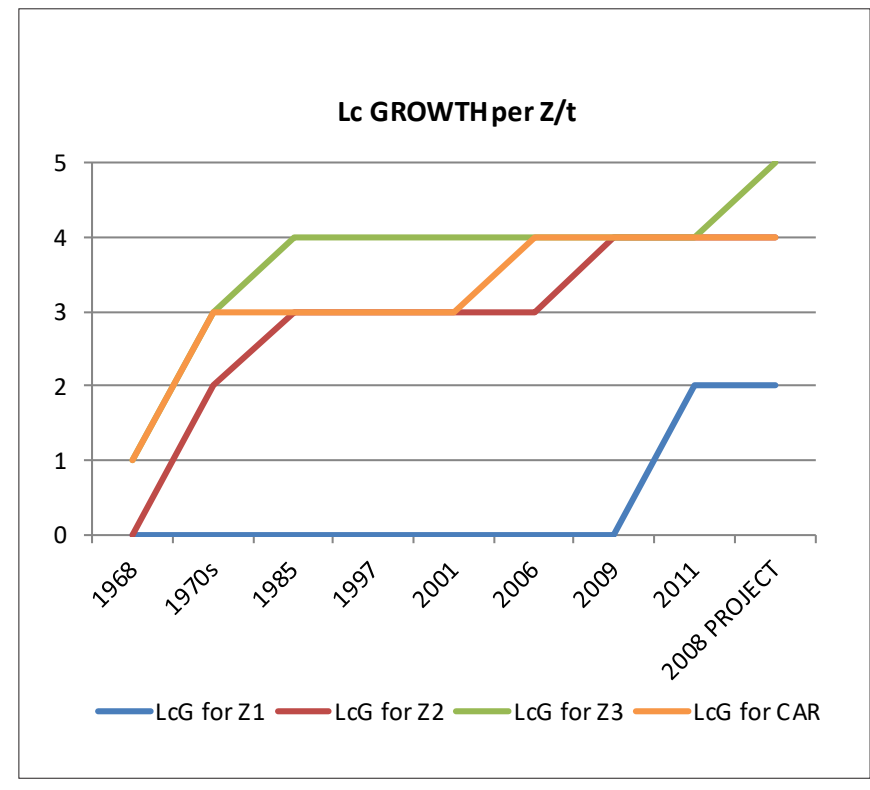

FIGURE 13. Growth of categorised loss per Zone through time.

to emphasise that with the actualisation of the planned quarrying the loss in Zone 3 would become complete and expressed with grade 5 . 


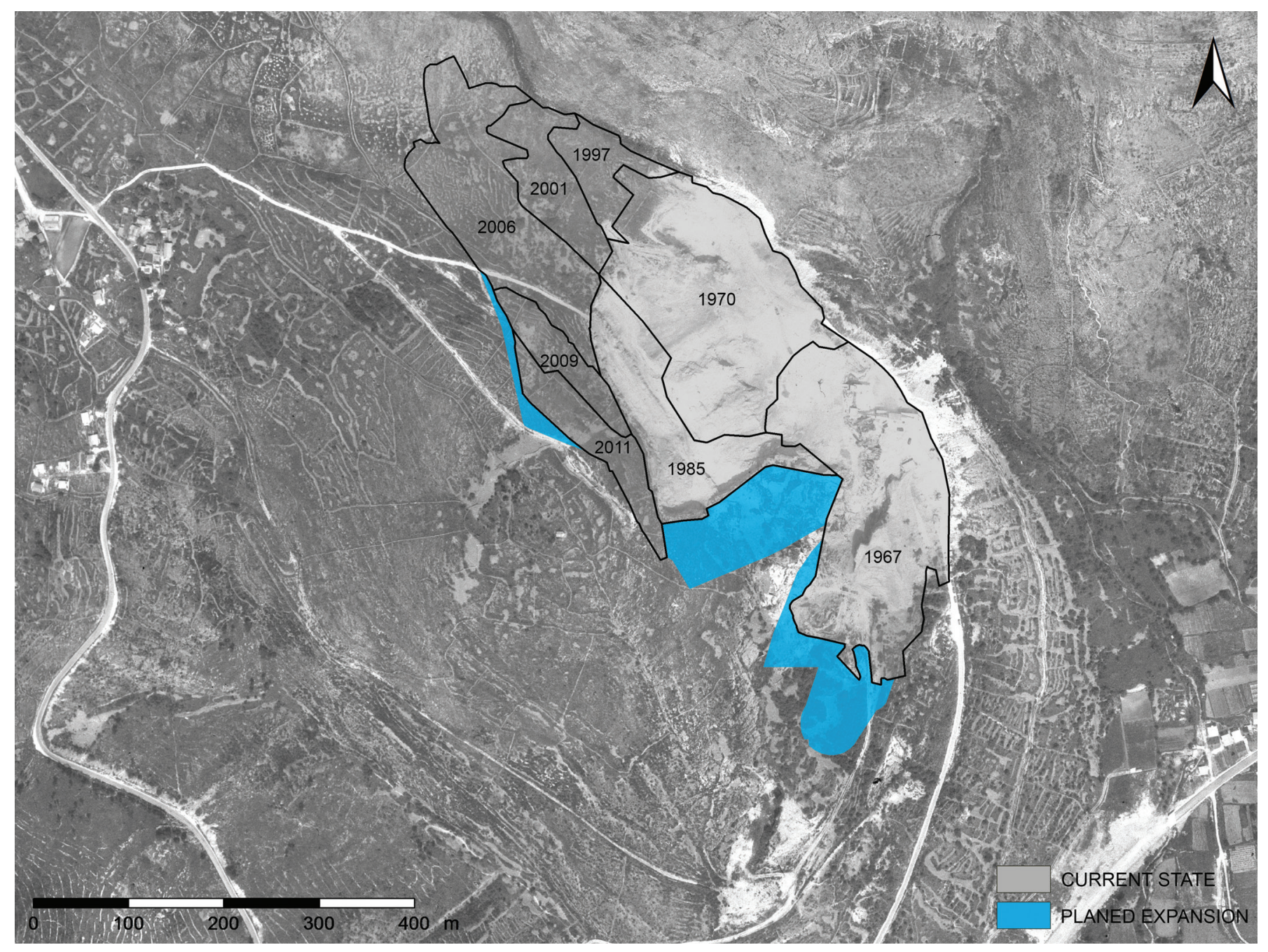

FIGURE 14. 2008 project of quarry expansion (made by: D. Tresić Pavičić; background: DGU, photo 1985_5364; source: Rudarsko-geološko-naftni fakultet 2008).

\begin{tabular}{|c|c|c|c|c|c|c|c|c|}
\hline & $\mathrm{Da} \mathrm{m} \mathrm{m}^{2}$ & $\mathrm{DaG} \mathrm{m}^{2}$ & Epd \% & EPdG \% & $\mathbf{L}$ & LG & Lc & LcG \\
\hline $\mathbf{Z 1}$ & 1139 & 6289 & 2 & 12 & 5.2 & 10.4 & 1 & 2 \\
\hline $\mathbf{Z 2}$ & 4767 & 32034 & 7 & 46 & 7.8 & 18.2 & 2 & 4 \\
\hline $\mathrm{Z3}$ & 989 & 74847 & 1 & 80 & 5.2 & 26 & 1 & 5 \\
\hline CAR & 6895 & 113170 & 3 & 52 & 5.2 & 20.8 & 1 & 4 \\
\hline
\end{tabular}

TABLE 7. Predictive value loss assessment for planned quarry expansion. 


\section{Concluding remarks}

The documentation collected as a part of the Sutilija project enabled the retrospective monitoring of the damage caused by the exploitation of stone, and the percentage of destruction was retrospectively calculated for the period of 50 years. The results of this type of analysis were suitable for the valorisation of the site and value loss assessment through different periods. The approach was developed in accordance with the possibilities of retrospective monitoring of a single archaeological site or entire landscapes (Storemyr 2004; Hamandawana et al. 2005; Skar et al. 2006; Mlinkauskienè 2010; Risbøl et al. 2014; Popović 2017) in situations where they are systematically subjected to harmful impacts and significant changes. Available data for this procedure included historical photographs and archival cadastral maps as well as topographic data and high-resolution 3D photogrammetry which enabled mapping of the visible features and reconstruction of characteristics of the hill permanently destroyed by the stone exploitation. This enabled retrospective analysis of the quarry-affected area and the extraction of data required for the application of VLA Model. Although the Model is not developed as a tool for objective and accurate calculation of loss, it is capable of performing archaeological analysis of damage in numerical relations (Sirovica 2019: 146). Thereby argued statements on the loss of value and meaningful ranking of loss is enabled, which can give a deeper understanding of the destroyed parts of the archaeological record and corroborated conclusions on the severity of damage. Accordingly, the aim of the presented approach is to broaden the understanding of the effects caused by long-term impacts on archaeological records and to enable the development of appropriate procedures within archaeological heritage management by means that capacitate the process of documenting changes and defining their scope. In everyday management practice, such an approach can greatly facilitate the analysis of similar situations and give strong arguments to the statements about damages on archaeological records. 


\section{References}

Babić, I. 1980. Gradine i gomile između Trogira i Splita u odnosu na prirodne puteve, In: N. Tasić (ed.), Putevi komunikacije u praistoriji, Materijali 16, Savez arheoloških društava Jugoslavije, Beograd, 61-67.

Babić, I. 1991. Prostor između Trogira i Splita: kulturnohistorijska studija, 2nd edition, Zavičajni muzej Kaštela, Kaštel Novi.

Barbarić, V. 2010. Late Bronze Age in Dalmatia: state of research, In: P. Cassola Guida and E. Borgna (eds.), From the Aegean to the Adriatic: Social Organizations, modes of Exchange and Interaction in the Post-Palatial Period (12th11th BC), Quasar, Roma, 311-323.

Burić, T. 2000. Arheološka topografija Drvenika i Ploče, In: I. Pažanin (ed.), Zbornik otoka Drvenika 1, Župa Sv. Jurja Mučenika, Drvenik, 417-447.

Burić, T. 2008. Arheološka topografija Vinišća (rezultati rekognosciranja), In: I. Pažanin (ed.), Viniščarski zbornik 2, Župa Presvetog Srca Isusova, Vinišće, 75-176.

Čače, S. 1992. Područje Kaštela na prijelazu iz prapovijesti u povijesno doba, In: Z. Gunjača (ed.), Kaštel-Sućurac od prapovijesti do XX. stoljeća, Muzej hrvatskih arheoloških spomenika Društvo za zaštitu kulturne baštine Podvorje, Split, Kaštel Sućurac, 33-47.

Čače, S. 2001. Putalj do početka povijesnog doba, In: T. Burić, S. Čače and I. Fadić (eds.), Sv. Juraj od Putalja, Muzej hrvatskih arheoloških spomenika, Split, 33-79.

Čače, S. and Milivojević, F. 2017. Rimski llirik u 1. st. pr. Kr.: nekoliko zapažanja, Vjesnik za arheologiju i historiju dalmatinsku 110 (2), 425-450.

Darvill, T. 2001. Value Systems in Archaeology and Heritage management, Archaeologisches Nachrichtenblatt 6 (2), 183-194.

Darvill, T., Saunders, A. and Startin, B. 1987. A Question of National Importance: Approaches to the Evaluation of Ancient Monuments for the Monuments Protection Programme in England, Antiquity 61, 393-408.

Fisković, C. 1957. Segetski spomenici, Vjesnik za arheologiju i historiju dalmatinsku 56-59 (2), 213-232.

Hamandawana, H., Eckardt, F. and Chanda, R. 2005. Linking archival and remotely sensed data for long-term environmental monitoring, International Journal of Applied Earth Observation and Geoinformation 7 (4), 284-298.

Katić, M. 1994. Utvrda Drid, Prilozi povijesti umjetnosti u Dalmaciji 34, 5-19.

Kirigin, B. 2010. Gradina Sutilija povrh Trogira i nalazi keramike tipa Alto-Adraitico, In: J. Dukić, A. Milošević and Ž. Rapanić (eds.), Scripta Branimiro Gabričević dicata, Kulturno društvo Trilj, Trilj, 23-55.
Madiraca, V. 2012. Stručno izvješće o zaštitnim arheološkim istraživanjima na arheološkim nalazištima Šupljak (AN 1), Procilj (AN 2), Njivice (AN 3) i Dabgora (AN 4) u perimetru izgradnje VE Jelinak, Pisa trade d.o.o., Split (upublished report).

Maršić, D. 2007. Heraklov žrtvenik iz Trogira, Archaeologia Adriatica 1, 111-128.

Miletić, A. 2006. Gradina Oriovišćak na Hiličkom poluotoku, Obavijesti Hrvatskog arheološkog društva 38 (2), 128-133.

Miletić, A. 2007. Prilozi topografiji Hiličkog poluotoka: Bristivica kod Trogira, Obavijesti Hrvatskog arheološkog društva 39 (2), 62-69.

Miletić, A. 2008a. Željeznodobna gradina na brdu Sutilija u Segetu, In: B. Olujić (ed.), Povijest u kršu: Zbornik radova projekta "Naselja i komunikacije u kontekstu veza Jadranskog priobalja i unutrašnjosti", Alpium Illyricarum Studia 1, Filozofski fakultet Sveučilišta u Zagrebu, Zagreb, 135-140.

Miletić, A. 2008b. Castellum Tariona, Vjesnik za arheologiju i povijest dalmatinsku 101, Split 2008, 59-74.

Miletić, A. 2009. Saltus Tariotarum, Opuscula archaeologica 32, 7-20.

Ministarstvo kulture Republike Hrvatske, Konzervatorski odjel u Trogiru 2007a. Rješenje o preventivnoj zaštiti, Class: UP/I-612-08/07-05/12522, Reg. no: 532-04-22/107-1, Trogir, 30. 05. 2007.

Ministarstvo kulture Republike Hrvatske, Uprava za zaštitu kulturne baštine 2007b. Rješenje, Class: UP-I 612-08/0706/0189, Reg. no: 532-04-01-1/4-07-2, Zagreb, 12.7. 2007.

Ministarstvo kulture Republike Hrvatske, Konzervatorski odjel u Trogiru 2011a. Rješenje o privremenoj obustavi, Class: UP/I-612-08/11-11/0036, Reg. no: 532-04-19/1-111, Trogir, 18. 03. 2011.

Ministarstvo kulture Republike Hrvatske, Konzervatorski odjel u Trogiru 2011b. Mjere zaštite, Class: UP/I-61208/11-03/0319, Reg. no: 532-04-19/1-11-2, Trogir, 12. 12. 2011.

Mlinkauskienè, A. 2010. Studies of Immovable Cultural Heritage Changes in Regional Parks of Lithuania, Aplinkos tyrimai, inžinerija ir vadyba / Environmental Research, Engineering and Management 52 (2), 70-79.

Narodne novine 12/2008. Ministrastvo kulture, Izvod iz Registra kulturnih dobara Republike Hrvatske br. 6/2007: Lista zaštićenih kulturnih dobara, Narodne novine, Zagreb, https://narodne-novine.nn.hr/clanci/sluzbeni/2008_01_12_352.html (Accessed: 2019. 01. 21.). 
Paraman, L. and Tresić Pavičić, D. 2015. Stručno izvješće o realizaciji programa "Istraživanje prapovijesnog naselja i dokumentiranje arheološke zone Sutilija": Arheološko istraživanje neinvazivnim metodama na lokalitetu Seget Gornji - Sutilija (gradina, kamenolom i crkva sv. Ilije), Muzej grada Trogira, Trogir (unpublished report).

Parica, M. 2014. Arheološki tragovi kamenarstva u Dalmaciji od prapovijesti do kraja srednjeg vijeka, Odjel za arheologiju Sveučilišta u Zadru, Zadar (unpublished PhD thesis).

Pašalić, G., Mužinić, M., Novak Mujanović, S., Čović Fornažar, K. Ananić, D. Fundarulja, D. and Mrkoci, S. 2016. Elaborat zaštite okoliša: Izmjena eksploatacije tehničkograđevnog kamena na eksploatacijskom polju "Segetsjever" spuštanjem u dubinu i smanjenjem površine eksploatacije - ocjena o potrebi procjene utjecaja na okoliš, IPZ Uniprojekt MCF d.o.o., Zagreb, https://www.mzoip.hr/ doc/elaborat_zastite_okolisa_513.pdf, (Accessed: 22. 03. 2018.)

Popović, S. 2017. Koliko je maslina potrebno da...? Valorizacija arheoloških nalazišta u Starogradskom polju / How many olives are needed to...? Valorization of archaeological sites in the Stari Grad Plain, Vjesnik za arheologiju i historiju dalmatinsku 110 (2), 577-599.

Risbøl, O., Briese, C., Doneus, M. and Nesbakken, A. 2015, Monitoring cultural heritage by comparing DEMs derived from historical aerial photographs and airborne laser scanning, Journal of Cultural Heritage 16 (2), 202-209.

Rudarsko-geološko-naftni fakultet 2008. Stručno mišljenje o radovima i stanju stabilnosti kosina na eksploatacijskom polju Seget-sjever, Rudarsko-geološko-naftni fakultet, Zagreb (unpublished report).

Schofield, J. 2000. Now we know: the role of research in archaeological conservation practices in England, In: F. McManamon and A. Hatton (eds.), Cultural Resource Management in Contemporary Society: Perspectives on Managing and Presenting the Past, Routledge, London, 76-92.

Sirovica, F. 2015. Ocena izgube vrednosti in znanstvenega informacijskega potenciala pri uničenih arheoloških depozitih, Filozofska fakulteta Univerze v Ljubljani, Ljubljana (unpublished $\mathrm{PhD}$ thesis).
Sirovica, F. 2019. Gubitak vrijednosti arheološkog zapisa: mogućnosti i načini procjene, Zavod za varstvo kulturne dediščine Slovenije, Znanstvena založba Filozofske fakultete Univerze $v$ Ljubljani, Ljubljana.

Skar, B., Solstad, J., Risan, T., Haugen, A., Bakkestuen, V., Erikstad, L. and Guttormsen, T. 2006. DEMOTEC - Development of a Monitoring System for Cultural Heritage through European Co-operation, In: M. loannides, D. Arnold, F. Niccolucci and K. Mania (eds.), The e-volution of Information Communication Technology in Cultural Heritage: Where Hi-Tech Touches the Past: Risks and Challenges for the 21st Century, Archaeolingua, Budapest.

Storemyr, P. 2004. Monitoring and risk assessment of monuments and archaeological sites in the Nemi basin, Colli Albani, Italy 1, Report, Expert-Center für Denkmalpflege, Zürich.

Škobalj, A. 1970. Obredene gomile: Na temelju arheoloških nalaza povijesno-teološka rasprava o religiji i magiji, Župa Svetog Križa, Čiovo.

Šuta, I. 2009. Prilog poznavanju prapovijesnih puteva u Dalmatinskoj zagori, Histria Antiqua 17, 147-156.

Šuta, I. 2010. Prilog poznavanju prapovijesne topografije na području Labina, Prgometa i Opora, In: J. Botić (ed.), Zbornik Opor i Kozjak - Spona priobalja i Zagore, Udruga za revitalizaciju sela Opor - Botići, Kaštela, 9-18.

Šuta I. 2011. Arheološka topografija okolnog područja / Archaeological Topography of the Surrounding Area, In: A. Babin (ed.), Antički Sikuli / Ancient Sikuli, Muzej grada Kaštela, Kaštela, 25-29.

Šuta, I. 2013a. Korištenje vrtača u prapovijesti srednje Dalmacije, Tusculum 6, 7-24.

I. Šuta, I. 2013b. Prapovijesna gradina Biranj na Kozjaku i topografija prapovijesnih nalazišta u okolici, Kaštelanski zbornik 10, 93-117.

Šuta, I. 2016. Prapovijest Kozjaka / Prehistory of Kozjak, Muzej grada Kaštela, Kaštela 2016.

Šuta, I. and Bartulović, T. 2007. Gradine Kaštela i okolice, Muzej grada Kaštela, Kaštela 2007.

Willems, W. J. H. and Brandt, R. W. 2004. Dutch Archaeology Quality Standard, Rijksinspectie voor de Archeologie, Den Haag. 